\title{
Hart, Austin, and the Concept of a Legal System: The Primacy of Sanctions
}

In 1961, H. L. A. Hart published The Concept of Law, his most extensive and systematic essay in general jurisprudence. ${ }^{1}$ Hart's book immediately received widespread critical attention. ${ }^{2}$ Today, The Concept of Law is generally regarded as an original and important work. Indeed, this is too cautious a claim: The Concept of Law has become an established classic. The core of Hart's argument is addressed to three related questions: What is a legal rule? What are the points of difference and similarity between law and morality? What is a legal system $^{3}$ This Note is concerned with Hart's answer to the last of these three questions, with his attempt, in The Concept of Law, to build up a coherent and satisfying picture of what a municipal ${ }^{ \pm}$legal system is.

In the opening chapter of The Concept of Law, Hart states that the purpose of his book is "to advance legal theory by providing an improved analysis of the distinctive structure of a municipal legal system and a better understanding of the resemblances and differences between law, coercion, and morality as types of social phenomena." Whether Hart's "improved analysis" yields anything as precise and unequivocal as a definition of what a legal system is-indeed, whether such a definition is possible at all-have been much-disputed questions. ${ }^{\circ}$ Hart himself appears to have been somewhat skeptical in this regard. At one point, he even offers several reasons for believing that "nothing

I. H. L. A. HART, The Concept of LAw (1961) [hereinafter cited as HART]. His other books include: CaUSATION IN THE LAw (1959) (with A.M. Honoré); LAw, LibERTY AND MoRAlity (1962); PUNishment AND Responsibility (1968).

2. For a general review of the more important treatments of the book in the secondary literature, see note 9 infra. An especially broad and original critique of Hart's concept of a legal system is contained in Ronald M. Dworkin's essay, Dworkin, The Model of Rules, 35 U. CHr. L. REv. 14 (1967). Dworkin's principal concern is with Hart's definition of a legal system as a system of rules delimited by a rule of recognition. Dworkin regards this definition as inadequate, and attempts to show that any developed legal system contains decisional criteria ("principles" and "policies") which "are not binding because they are valid under standards laid down by a master rule but are binding-like the master rule itself-because they are accepted as binding by the community." Id. at 44 . For a critique of Dworkin's attack upon the view that a legal system can be adequately characterized as a system of rules, see Note, Understanding the Model of Rules: Toward a Reconciliation of Dworkin and Positivism, 81 YALE L.J. 912 (1972).

3. Hart himself includes a fourth question: "How ... do law and legal obligation differ from, and how are they related to, orders backed by threats?" HaRT 7 . His answer to this question is, however, part of his general discussion of legal rules. See id. at 79-88.

4. Hart uses the term "municipal" in the sense defined in 1 THE CoMpact Edition of THE OXFORD ENGLISH DICTIONARY 767 (1971): “pertaining to the internal affairs of a state as distinguished from its foreign relations." Hart's usage has been followed in this Note.

5. HART 17.

6. See note 7 infra. 
concise enough to be recognized as a definition could provide a satisfactory answer" to the question, "what is law?"7 Nevertheless, despite his own methodological reservations, Hart does, in fact, attempt to isolate and specify a set of "central elements" 8 peculiar to legal systems, and in this way to distinguish law from those related social phenomena with which, in his view, it has been wrongly identified.

As a result, The Concept of Law is a deeply ambiguous book. It appears, at times, that Hart would like to have his cake and eat it too: to define the concept of a legal system, while protesting that such a definition must be impossible or uninteresting or both. This approach has its advantages. In particular, it insulates Hart's concept of a legal system from critical scrutiny by making any attempt to formulate that concept with precision and simplicity appear suspect, an unwarranted bit of dogmatism entirely out of keeping with the mildly skeptical spirit of Hart's inquiry.

This Note begins with the assumption that Hart makes a serious effort in The Concept of Law to define the distinguishing features of a legal system. In order to extract from the book a convincing account

7. HART 16. For Hart's own reasons for believing that such a definition is impossible, sce $i d$. at 13-17. For an extended discussion of the same problem, see Sartorius, Hart's Concept of Law, in More Essays in Legal Philosophy 131, 142-44, 153-55 (R.S. Summers ed. 1971). According to Sartorius, the term "Iaw" is an example of what Hilary Putnam has called a "cluster concept." Cluster concepts are distinguished by the fact that "few, if any, of the conditions associated with them (i.e., satisfied in the standard or paradigm cases of their correct application) are individually necessary, and those which are necessary are not jointly sufficient." Id. at 142. It is therefore impossible, on this view, to frame a list of necessary and sufficient conditions associated with legal systems generally, that is, to define the concept of a legal system.

The theory of cluster concepts closely parallels Wittgenstein's discussion of "family resemblances." L. Wittgenstein, Philosophical Investigations If 66-67 (3d. ed. 1968). It is likely that Hart's doubts concerning the possibility of satisfactorily defining the concept of law or a legal system are due to the pervasive influence which Wittgenstein's own skepticism about definitions had upon him. See Harr 234.

Even supposing, however, that no list of conditions necessary and sufficient for the definition of a legal system could be enumerated, a clarification of the resemblances and differences between law and other forms of social control would still require that the principal distingtishing features of what Hart calls the "standard case" of a legal system be marked off and isolated. Id. at 4 . If these features cannot be isolated at all (that is, if the standard case is indistinguishable from the "doubtful cases" associated with it), then it is fair to conclude that no definition of the concept of a legal system is possible. To the extent that the standard case of a legal system is distinguishable from other forms of social control, even if only partially or imperfectly, there can be nothing absurd or objectionable in the search for a definition of law. Another way of putting this is to say that the proposition that law is a cluster concept ought not to be construed as a denial that law can be defined, but rather as a theory about the nature and limits of such a definition.

The search for a definition of law, or for an adequate account of the nature of law, is not really something mysterious, though what will bring it to a successful conclusion may be; it is the search for the distinctive, central, and important features that mark off a complex and important social phenomenon. The fact of borderline cases and the fact that there may be no set of properties common and peculiar to law cannot show that the search is misguided.

Singer, Hart's Concept of Law, 60 J. PHIL. 197, 200 (1963).

8. HART 79. 
of what a legal system is, and thereby do justice to Hart's own efforts, it is necessary, however, that great importance be attached to an aspect of his analysis of law that Hart himself regarded as relatively unimportant and to which he devoted only a few scattered pages; and conversely, that little importance be attached to those arguments in The Concept of Law that comprise the most extensive, and apparently on Hart's view most original, part of the book. Obviously, this approach distorts Hart's own priorities. At the same time, however, it salvages his claim to have isolated the distinguishing features of a legal system.

It is the thesis of the first part of this Note that Hart's concept of a legal system turns upon his analysis of the distinctiveness of legal sanctions, and that Hart's account of the peculiar nature of legal sanctions provides the most convincing basis to be found in The Concept of Law for distinguishing legal systems from other types of social phenomena. ${ }^{9}$

The aim of the second part of the Note is to demonstrate the similarity between Hart's concept of a legal system and that of his principal polemical adversary, John Austin. A good part of The Concept of Law is devoted to an attack upon the theory of legal obligation formulated by Austin in The Province of Jurisprudence Determined. ${ }^{10}$ When Hart remarks that the purpose of his book is "to advance legal

9. In the 13 years since The Concept of Law was first published, a number of articles in philosophical and legal journals have sought to clarify Hart's conception of the distinctive structure of municipal law. Generally speaking. Hart's commentators have maintained that the core of his concept of a legal system is to be located either in his analysis of rules and rule-governed behavior, see Dworkin, supra note 2, or in his rather extended discussion of the difference between legal and moral obligation, see Sartorius, supra note 7.

In attempting to explicate his definition of a legal system, many of Hart's commentators have ignored his theory of legal sanctions. See Dworkin, supra note 2; Hughes, Professor Hart's Concept of Law, 25 MoD. L. Rev. 319 (1962); King, The Basic Concept of Professor Hart's Jurisprudence: The Norm out of the Bottle, 1963 CAMBRIDGE L.J. 270; Mullock, Some Comments on Professor Hart's Legal System-A Reply to Professor Summers, 1965 Duke L.J. 62; Singer, supra note 7; Summers, Professor H.L.A. Hart's Concept of Law, 1963 Duke L.J. 629; Taylor, H.L.A. Hart's Concept of Law in the Perspective of American Legal Realism, 35 Mod. L. Rev. 606 (1972); Brown, Book Review, 72 PHIL. Rev. 250 (1963); Cohen, Book Review, 71 Mind 395 (1962); Morris, Book Review, 75 Harv. L. Rev. 1452 (1962); Noonan, Book Review, 7 NAT'L L.F. 169 (1962); Ross, Book Review, 71 Yale L.J. 1185 (1962). Others have argued that his definition is incomplete because of the absence of any such theory. See Cameron, Observations on the "Concept of Law", 8 JuR. REv. (N.S.) 101 (1963); Kanowitz, The Place of Sanctions in Professor H.L.A. Hart's Concept of Law, 5 DuQ. L. REv. 1 (1966).

If Hart's commentators have failed to appreciate the central position which Hart's theory of sanctions occupies in his concept of a legal system, they have only been following Hart's own lead. At various points in The Concept of Law, Hart himself appears to assert the view that "law without sanctions is perfectly conceivable." Harr 38. Law without sanctions may very well be conceivable. But whether Hart's concept of a legal system turns upon a theory of sanctions is an entirely different matter. If it does-and it is the aim of the first part of this Note to demonstrate that it does-then what we must conclude is that Hart's belief that law without sanctions is perfectly conceivable is not justified by his own concept of a legal system.

10. J. Austin, The Province of Jurisprudence Determined, etc. (1954 ed.) [hereinafter cited as AUsTIN]. 
theory by providing an improved analysis of the distinctive structure of a municipal legal system," what he principally has in mind is an advance beyond Austin's concept of a legal system. Hart's main criticism of Austin's concept of a legal system is that it does not include the idea of a "rule."11 Although a plausible argument can be made to the effect that Austin's concept of a legal system does, in fact, include the idea of a rule, ${ }^{12}$ it cannot be denied that Hart formulates this idea with a degree of precision unapproached in Austin's writings.

The centrally important element in Hart's concept of a legal system is not, however, the idea of a rule. The core of Hart's concept of a legal system, this Note argues, is to be found in his analysis of legal sanctions. A similar analysis of legal sanctions occupies an equally central position in Austin's concept of a legal system. The conclusion to be drawn is that Hart's concept of a legal system resembles Austin's far more than has been suspected, and represents far less of an advance beyond Austin's "analysis of the distinctive structure of a municipal legal system" than either Hart or his admirers might wish.

\section{Hart's Concept of a Legal System}

\section{A. The Form and Content of a Legal System}

\section{Primary and Secondary Rules}

Hart's own positive answer to the question, "What is a legal system?", is built upon his critique of Austin, a critique which occupies three full chapters in The Concept of Law. ${ }^{13}$ According to Hart, this extended treatment is warranted because the mistakes of the Austinian conception of law are themselves illuminating: they are basic mistakes which, when correctly understood, point the way toward a more sophis-ticated and compelling legal theory.

Hart claims that the Austinian definition of law is built up from "the apparently simple elements of commands and habits," 14 the "ideas of orders, obedience, habits, and threats." ${ }^{15}$ According to Hart, Austin's definition is inadequate because it does not include the "idea of a rule,"16 that is, the idea of a standard which functions as a "reason

11. See pp. 587-88 infra.

12. See p. 602 infra.

13. HART 18-76.

14. Id. at 18 .

15. Id. at 78 .

16. Id. 
or justification" 17 for doing or not doing certain things. The "critical reflective attitude"18 or "internal aspect"19 which distinguishes the "normative structure of society"20 presupposes the existence of rules and their use as standards for the evaluation and justification of social conduct. Consequently, the idea of a rule is required to explain any structure of authority ${ }^{21}$ or obligation, ${ }^{22}$ since part of the meaning of either is that those participating in such a structure not only do certain things, but seek to justify what they do as well. And, because both authority and obligation are features of every legal system, without the idea of a rule "we cannot hope to elucidate even the most elementary forms of law." 23

According to Hart, then, a legal system must be a system of rules. But taken by itself, the general property of being rule-governed is not enough to distinguish a legal system from any other social institution which employs principles or standards of justification. Moral systems, social customs, and games are examples-Hart's own, in fact-of systems of conduct, ordered in accordance with rules, which are not themselves legal systems. ${ }^{24}$ Hart himself recognizes that the distinctive structure of a legal system cannot consist in its being simply a system of rules. Accordingly, in order to account for the distinguishing features of a legal system, Hart introduces a number of additional elements into his analysis. The first addition is the assertion that law is a union of two distinct types of rules, which Hart terms "primary" and "secondary." "Rules of the first type concern actions involving physical movement or changes." ${ }^{26}$ Rules of the second type specify how rules of the first type are to be created, amended, abolished, interpreted, and applied. Thus while primary rules regulate behavior, secondary rules regulate or inform other rules. The two types of rules operate upon logically distinct subject matters. Consequently, the conceptual assimilation of one to the other is impossible. Hart makes what is for him the unusually sweeping assertion that "in the combination of these two types of rules lies what Austin wrongly claimed to have found in the notion of coercive orders, namely, 'the key to the science of jurisprudence.' "27

17. Id. at 82 .

18. Id. at 56 .

19. Id. at 55 .

20. Id. at 86 .

21. Id. at 57 .

22. Id. at 79-88.

23. Id. at 78 .

24. Id. at 55-56, 165.

25. Id. at 78 .

26. Id. at 79 .

27. Id. 
But like the general proposition that law is a system of rules, the more specific claim that law is a union of primary and secondary rules fails to define the distinctive structure of a legal system. Many institutions which are not themselves legal systems exhibit this same union of primary and secondary rules. An example, which has already been exploited by another philosopher to make this point, ${ }^{28}$ is the National Football League. Some of the rules which are observed by the players and officials of the League specify how the game of football is to be played (for example, how points are scored, when the game begins and ends, what constitutes a personal foul and how it is penalized). These rules fit Hart's description of primary rules. But the League also has rules which specify how the rules of play may be changed and who has the authority to interpret and apply ambiguous rules, such as the rule prohibiting "intentional" grounding of the ball. These rules can only be described as "secondary" rules in Hart's sense.

It seems fair to conclude that any practice or institution which orders human conduct by means of rules, and which is complicated or important enough to require a regular procedure for determining how these rules are to be made, modified, interpreted, or applied, will consist of a union of primary and secondary rules. Such a union is not peculiar to legal systems, and therefore cannot serve as the touchstone for distinguishing legal from other forms of social control. If Hart's concept of law went only this far, it would not be a concept of law at all.

\section{The Minimum Content of Natural Law}

It is Hart's contention that every legal system is a union of primary and secondary rules. But in addition to this merely formal property, Hart claims that all legal systems also share a certain minimum content, which he calls the "minimum content of Natural Law."29

According to Hart, the truth of this claim rests upon the observation that "most men most of the time wish to continue in existence" 30 or survive. In "the modest aim of survival" Hart locates "the central indisputable element which gives empirical good sense to the terminology of Natural Law." ${ }^{11}$ Of course, this view represents only a "very attenuated version" 32 of the classical Natural Law doctrine which sought, above all else, to distinguish those lives which were good and

28. See Sartorius, supra note 7, at 139. Undoubtedly, the World Football League would be an equally appropriate example.

29. HART 189.

30. Id. at 187 .

31. Id.

32. Id. 
desirable from those which were not. ${ }^{33}$ Hart claims, however, that this attenuated version of Natural Law possesses great strength since its obvious truth "can be disentangled from more disputable parts of the general teleological outlook in which the end or good for man appears as a specific way of life about which, in fact, men may profoundly disagree."34

Given a few universal-but nevertheless contingent-facts about human nature and the world in general, ${ }^{35}$ such as human vulnerability to bodily attack, approximate equality in physical size and strength, and the relative scarcity of natural resources, it follows that "there are certain rules of conduct which any social organization must contain if it is to be viable," 36 that is, if it is to secure the basic human aim of survival. Thus, if a social organization is to avoid becoming a "suicide club," 37 it must restrict the free use of violence among its members, ${ }^{38}$ provide for a "system of mutual forbearance and compromise," 30 establish a cooperative division of labor, ${ }^{40}$ and so on. Hart enumerates a series of such rules of conduct which, taken together, form the necessary "minimum content of Natural Law" that any moral or legal practice must contain if it is to endure.

Hart most often speaks of this "minimum content" as if it were a distinguishing feature of moral and legal systems in particular. In fact, this "common element" of Natural Law is really a precondition for the continued existence of any social organization whatsoever, or for the association of men in general. Absent this "common element," social life in its entirety-and not merely in its legal and moral aspectswould disappear. Consequently, although Hart's analysis of the "minimum content of Natural Law" is unimpeachable (since, as Hart admits, the propositions on which it rests are truisms), ${ }^{41}$ it nevertheless fails to bring us any closer to an understanding of the specific and distinguishing structure of a legal system.

\section{B. Hart's Analysis of the Distinction between Law and Morality}

Even if we assume that moral and legal systems are the only ones which contain what Hart calls the "minimum content of Natural Law,"

33. See ARISTOtLe, Nicomachean Ethics * 1095a (13)-1096a(10), 1097a(15)-1099b(10).

34. Hart 187.

35. "Contingent" because Hart assumes these facts to be empirically uniform and invariable, but not logically necessary.

36. Id. at 188.

37. Id.

38. Id. at 190 .

39. Id. at 191 .

40. Id. at 192.

41. Id. at 189 . 
an adequate account of what a legal system is would still have to include grounds for distinguishing law from morality. A good part of The Concept of Law is devoted to just this problem.

According to Hart, there are "four cardinal related features which collectively serve to distinguish morality not only from legal rules but from other forms of social rule"42 as well. Hart's detailed discussion of these four features represents the core of his attempt to elucidate the distinctive structure of a legal system. Consequently, each of the four features which Hart isolates deserves critical scrutiny. The arguments which follow are designed to show that, in fact, only one of these four features distinguishes law from morality in a principled and thoroughgoing way, and that this feature therefore is the best test which Hart offers for distinguishing law from other forms of social control.

\section{The Nondeliberate Character of Moral Change}

The first criterion that Hart offers for distinguishing morality from law is that while "new legal rules can be introduced and old ones changed or repealed by deliberate enactment... by contrast moral rules or principles cannot be brought into being or changed or eliminated in this way." 43 But it is not hard to conceive of a moral system that falls on the wrong side of the line this test would draw. ${ }^{44}$

We can imagine, without much difficulty, a community of individuals bound together by a set of rules which define their moral obligations to one another, as well as to those outside of the community, which is nevertheless not itself a legal system. A religious sect existing within the territorial jurisdiction of a secular state is one example of such a community. If we refine our imaginary picture by assuming, in addition, that the members of this community all believe that the ethical pronouncements of one particular member are morally binding upon the others, we do not necessarily transform our imaginary community into a legal system. It is perfectly conceivable that such a moral legislator is regarded by the other members of his community as a prophet who is peculiarly qualified to lay down rules of moral conduct for

42. Id, at 169 .

43. Id. at 171 .

44. In order to test the validity of this distinction, it is necessary to conduct a thought experiment. Can we imagine a system of moral conduct whose rules can be "brought into being or changed or eliminated" deliberately? It should be noted that this experiment requires that we already have a set of intuitions about what is, and what is not, a system of moral conduct. There is nothing objectionable in this. Hart's own account of the differences between law and morality rests upon a similar presupposition. The real ques. tion is whether Hart's account fits our intuitions, or is at variance with them. This approach accords with the idea of "reflective equilibrium" formulated by J. RAwLs, A THEORY OF Justice 48-51 (1971). 
the community as a whole. If so, he may very well possess the authority to make and unmake the community's morality, by proclamation.

Empirical examples of such a community may be found in those systems of morality that have grown up on the basis of charismatic proclamation. ${ }^{45}$ Typically, the rules of life conduct laid down by a charismatic prophet mark a sudden and complete break with prevailing norms. Such systems are distinguished from traditional and established patterns of ethical conduct by the very deliberateness with which their guiding principles have been formulated.

The basic error underlying Hart's contention that moral rules cannot be deliberately enacted or changed is his mistaken belief that all moral rules are like traditions. ${ }^{46}$ This view of morality is unjustifiably narrow. The purpose of the example we have just offered was to show that, contrary to what Hart contends, there is nothing absurd in the idea that standards can be "endowed with, or deprived of, moral status by human fiat."47

Of course, it might be objected that the example proves Hart's point, since in our imaginary community the belief of the members that they are morally obliged to observe their leader's proclamations does not itself rest upon a rule which has been, or could be deliberately laid down. This objection proves too much, however; on Hart's view (a view explored in the next section), the authority of those who are responsible for enacting and modifying the laws of a legal system also rests upon a practice of acceptance which cannot be deliberately enacted.

Deliberate enactment is not a property or characteristic which necessarily distinguishes law from morality.

\section{The Necessary Importance of Moral Rules}

Hart's second ground for distinguishing morality from law rests on the proposition that "importance is not essential to the status of all legal rules as it is to that of morals." 48 By this Hart means that while a law that is "generally thought quite unimportant to maintain" re-

45. See 1 M. WEBer, Economy AND Society 241-54 (G. Roth \& C. Wittich eds. 1968); 3 id. at 1111-56. See generally N. CoHN, THE PURSUIT of THE MILLENNIUM (1961).

Of course, the prophet claims that his prophecy is legitimate and therefore binding upon the members of his community because he is God's authorized spokesman. But in this regard, he is in the same situation as a lawmaker who asserts that the laws he has made are legitimate not merely because he has made them, but because he has made them in accordance with, and on the basis of, the authority which has been constitutionally delegated to him (whether the constitution be written or not).

46. HART 172.

47. Id. at 171 .

48. Id. at 170 . 
mains a legal rule until repealed, by contrast, it would "be absurd to think of a rule as part of the morality of a society even though no one thought it any longer important or worth maintaining." 49

The force of this argument derives from Hart's distinction between acceptance and validity. According to Hart, all of the rules of a legal system except one, the rule of recognition, belong to that system by virtue of their legal validity. They are part of the legal system regardless of whether they are observed or enforced, because they derive from or pass "all the tests" 50 contained in the rule of recognition. That rule itself is neither valid nor invalid, for while it is the criterion in accordance with which the validity or invalidity of all the other rules of the legal system is determined, "there is no rule providing criteria for the assessment of its own legal validity." 51 The rule of recognition is included in the legal system, but its inclusion rests upon a different ground: upon the fact that it is "simply accepted as appropriate for use." 52 Thus, for Hart, any rule-other than the rule of recognitionmay be part of a legal system, may exist as a legal rule, despite the fact that it is not accepted (i.e., observed or enforced) as long as it passes the tests of legal validity stipulated by the rule of recognition itself. Hart's argument that importance is a necessary feature of all moral rules amounts to the contention that the distinction between acceptance and validity has no application to moral systems, i.e., that a rule or principle can be part of a moral system only if it is "accepted as appropriate for use."

This view is a mistaken one. There is no absurdity in thinking that a particular moral rule belongs to a system of such rules despite the fact that it is neither observed nor enforced. A rule may belong to a system of moral rules if it meets the criteria of validity specified by that system's rule of recognition, and despite its nonacceptance in practice.

Obviously, what this view depends upon is the assumption that a moral system may be complex enough to contain rules of two sortsthose which belong to the system merely because they are accepted as "appropriate for use," and those which belong because they satisfy all of the tests laid out in some master rule, or rule of recognition-without thereby automatically becoming a legal system. That this assumption is justified may be seen by considering the following example.

49. Id. at $170-71$.

50. Id. at 100 .

51. Id. at 104

52. Id. at 105 . 
Imagine a church with many members and a long history which has never been, at any time, a legal system. Because the church imposes many different moral obligations on its members, it happens from time to time that these obligations come into conflict with one another, one commanding what the other prohibits. In order to resolve such conflicts, a council is established to review any serious inconsistencies that may arise because of competing moral obligations, and to declare which obligation the members of the church are to recognize. Let us assume that long ago this council decided that the moral well-being of the members would be advanced by requiring that each member make a regular confession of his or her moral failings to a local representative of the council itself. And let us further assume that the council recorded this decision in a special book which it keeps to insure that its decisions are consistent.

Suppose that after a period of time, the members of the church cease to make regular confession as the council had required, and that the local representatives of the council, who are far too busy with other matters, no longer insist that they do so. The rule that all church members are to make regular confession ceases either to be obeyed or enforced. Can we say that the rule continues to be part of the system of moral rules recognized by the members of the church?

However we decide this question, a conclusion that the rule requiring confession is part of the moral system of the church would be no more absurd than the conclusion that a minor traffic regulation which is neither obeyed nor enforced belongs properly to a particular legal system. Both conclusions would make sense (or nonsense) for the same reason.

What we would want to say about one rule could equally well be said about the other: It is a valid rule, despite the fact that it is not "accepted as appropriate for use." In either case, the claim that the rule belongs to a system of rules merely means that the rule was promulgated in accordance with a procedure that is recognized as authoritative.

Hart limits his analysis to moral systems of a very primitive sort, i.e., to those which are composed exclusively of primary rules. In such systems, questions concerning the validity of any particular rule are not likely to be distinguished from questions concerning its acceptance. With this focus, Hart ignores the possibility that a moral rule might remain the rule of a particular moral community, especially a complex moral community like a church, even though it is no longer thought "important or worth maintaining." 


\section{Moral and Legal Responsibility}

The third basis which Hart offers for distinguishing law from morality is that

legal responsibility is not necessarily excluded by the demonstration that an accused person could not have kept the law which he has broken; by contrast, in morals 'I could not help it' is always an excuse, and moral obligation would be altogether different from what it is if the moral 'ought' did not in this sense imply 'can'.53

Put simply, Hart's claim is that while a legal system may "for certain types of offence, impose 'strict liability' and make responsibility independent of mens rea altogether, except perhaps for the minimum requirement that the accused must possess normal muscular control," strict liability in morality is unthinkable. This claim is a plausible one. Its apparent force derives, however, from Hart's equivocal and misleading use of the concept of legal responsibility.

If we think of an individual's legal responsibilities as including all and only those things which the law requires him to do or to refrain from doing, it follows that the legal "ought" implies "can" to the same extent (and for the same reasons) that the moral "ought" does. Hart acknowledges that this is true of the majority of responsibilities which a legal system imposes; he denies, however, that it is true of those "types of offense" which rest upon a strict liability. What Hart fails to appreciate is that even these "types of offense," if they may be said to impose responsibilities in the sense defined above, rest upon an underlying "can" and have an exact moral analogue.

Rules of strict liability which impose upon the liable party a responsibility to act in a certain way are of the following form: When event $\mathrm{X}$ happens, person $A$ must do something (make compensation to another person $B$, pay a fine to the state, etc.), despite the fact that the happening of event $X$ was in no way subject to the control of person $A{ }^{\mathrm{WV}}$ It is of course true that $A$ cannot excuse himself from the duty

53. Id. at 174 .

54. Id.

55. It should be cmphasized that laws holding individuals responsible for actions which they could not possibly prevent occupy but a small place in any modern legal system. Many laws which might appear, at first glance, to impose such a strict liability rest in fact upon a presumption that it is within the power of the liable party to control or prevent the action in question. This is true, for example, of those laws which hold an cmployer responsible for the tortious conduct of his employee, so long as the employee's conduct remains within the scope of his employment. It is no objection that here the presumption of control is often a mere fiction; for the fact that the fiction is required in 
imposed by the rule on the grounds that the happening of $X$ was not within his control: if he could, the liability imposed by the rule would not be strict. But what if $A$ seeks to excuse himself on the grounds that he is unable to perform the duty which the rule imposes (if he says, for example, that he has no money with which to compensate $B$ )? An assumption is built into the rule that $A$ is capable of performing the duty which the rule imposes, even if he was utterly unable to prevent the happening of $X$. The rule tells $A$ that he must do something if $X$ happens; it is not a prediction that he will in fact do it. This much follows from Hart's own analysis of rules. ${ }^{56}$ And to the extent that the rule commands $A$ to do something, to the extent that it imposes an obligation on $A$ at all, it presupposes that what is required of $A$ is within his power to perform.

Of course, this presupposition may not always accord with the facts. If $A$ is penniless, he is (at least temporarily) unable to compensate $B$. Furthermore, $A$ 's poverty may be a mitigating factor, which provokes judicial leniency or even forgiveness (and this will depend, perhaps, on whether $A$ was robbed of all his money-a loss beyond $A$ 's control-or foolishly gambled it away-a loss regarded as within his control). The important point is that the presupposition remains; $A$ 's inability to compensate $B$ is not an excuse which merely has to be asserted in order that $A$ be released from his obligation to do so.

When strict legal liability is dissected in this way, it becomes clear that it has a moral analogue. In a great many instances, we acquire moral obligations as a result of the happening of some event utterly beyond our control. Thus, a citizen of a particular state may have a positive moral obligation to help eradicate an institution which existed long before he was born and which he had no part in making: racism in America would be an example. An individual may have a moral obligation to develop his talents, and be held blameworthy for not doing so, despite the fact that he acquired his talents, at least in part, through an accident of birth.

What if someone says, however, that he should not be blamed for failing to develop his talents? Here, of course, everything turns upon the excuse which he offers to explain his failure. If he says he should not be blamed because he is an essentially weak person who lacks the necessary discipline, he has failed to give an adequate excuse since it

order to justify the law dramatizes the difficulty we have in imposing a legal "ought" without presupposing an underlying "can." In the example used here, a rule of perfectly strict liability is postulated in order that Hart's argument be presented in its strongest form.

56. Id. at $87-88$. 
is precisely such discipline which the moral rule commands him to develop. A weak man who squanders his talents may evoke pity and solicitude; he is nevertheless a moral failure. We hold him to blame for his conduct because, in the last analysis, his weakness is his own fault.

If, however, someone is struck by a crippling disease, it would be unfair not to readjust or temper (but perhaps not dismiss entirely) our belief that he has a moral duty to develop his talents. In this respect, moral and judicial forgiveness are much alike. Once again, the important point is that moral responsibility-like its legal counterpartis not automatically dissipated by the magic formula, "I could not help it."

In both law and morality, obligations may be conditioned on events beyond the control of the individual upon whom the obligation is imposed. And, in both law and morality, the imposition of any obliga. tion necessarily presupposes that the obligation can be satisfied, although, in both law and morality, this presupposition may be overridden in particular cases. While the event which triggers a moral or legal obligation may be defined as being beyond one's control, the action which the obligation prescribes or prohibits cannot be. This fact, far from marking a distinction between law and morality, points to one of their deepest affinities.

There is, however, one situation in which Hart's distinction makes sense. Consider the following example. $A$ is arrested for the possession of a dangerous drug (a crime, in $A$ 's country, let us assume, with no scienter requirement whatsoever). The drug was mailed to $A$ without his knowledge, and wrapped in a package whose contents $A$ could not discern. $A$ is arrested at the post office, after picking up the package but before he has had a chance to open it. He is tried and convicted of the crime of possession and sentenced to a term in prison. Although $A$ has broken a rule of law, there is no sense in which he can be said to have violated a rule of morality.

Although this example illustrates an important difference between law and morality, the difference cannot be expressed in terms of the concept of responsibility, at least not in terms of the concept as it was defined above. It is true that $A$ has broken a rule of law; the rule which he has broken, however, did not require him to do or refrain from doing anything. The rule does not include an "ought" directed to $A$ at all. The rule merely says that something will be done to $A$ upon the happening of an event which might well be beyond $A$ 's control, that $A$ will be punished or sanctioned for the possession of a dangerous drug 
despite his own ignorance regarding the fact of possession. If what Hart is claiming is that a legal sanction may be imposed in such a case, but that a moral sanction cannot be, then his claim has a significant element of truth. But this distinction does not turn upon some difference between legal and moral responsibility; or if one wants to insist that it does, the concept of responsibility must be redefined in terms of the concept of a sanction. Our legal responsibilities include all and only those acts whose commission or omission may be made the occasion for the application of a legal sanction. On this view, the peculiar character of legal responsibility would appear to be dependent upon the peculiar character of legal sanctions.

In fact, the fourth and last reason which Hart gives for distinguishing law from morality is that they employ different types of sanctions. Hart's account of the distinctiveness of legal sanctions provides his most compelling answer to the question, "what is a legal system?"

\section{Moral and Legal Sanctions}

According to Hart, "rules are conceived and spoken of as imposing obligations when the general demand for conformity is insistent and the social pressure brought to bear upon those who deviate or threaten to deviate is great." 57 An insistent and serious social pressure of this sort is characteristic of legal and moral systems alike and serves, in a rough and ready way, to distinguish both of them from those systems of conduct which attach only a limited importance to the breach of their rules.

While it is true that the observance of both legal and moral rules is treated as a serious matter, the forms of pressure brought to bear in their enforcement are typically quite different. According to Hart, legal rules are primarily enforced through the threat and actual use of "physical sanctions"; 58 by contrast, the typical form of moral pressure "consists in appeals to the respect for the rules, as things important in themselves, which is presumed to be shared by those addressed." 59

Although this point is an important and illuminating one, Hart puts it in a somewhat misleading way. In the first place, those appeals to conscience which Hart associates with the enforcement of morals also play an important role in the enforcement of the rules of a legal system. This is especially true with respect to self-enforcement, where obedience to the law is often based upon the belief that one has a

\footnotetext{
57. Id. at 84 .

58. Id.

59. Id. at 175 .
} 
moral obligation to do as the law commands. That the appeal here is to a moral belief, or to one's conscience, does not alter the underlying fact that in this situation the appeal operates as an instrument of law enforcement. More importantly, there is nothing absurd in the idea of a moral system which stipulates that certain classes of wrongdoers ought to be punished by the application of physical sanctions. The fact that the use of such sanctions for a moral purpose may itself be a legal offense does not invalidate this point.

If this is so, what can Hart mean when he asserts that laws are typically enforced by the use (or threatened use) of physical sanctions, whereas moral rules characteristically rely, for their enforcement, upon "appeals to conscience" and "the operation of guilt and remorse"?oo The best way to make sense of this assertion is to treat it as equivalent to the following proposition: where the rules of a particular system of conduct are enforced by the application of physical sanctions, that system will be a legal system insofar as, and to the extent that, with respect to the conduct it regulates no other or independent set of rules is effectively enforced in a similar manner. Or, put negatively, a particular set of rules is not a legal system if it is unable to punish breaches with physical sanctions. Thus, while a moral system may prescribe physical punishment for those who break its rules, so long as the imposition of such punishment is effectively prohibited by the officials responsible for enforcing an independent system of rules (through the use of physical sanctions if necessary) it will remain a moral system. It is just at the point where this disability is overcome that it is no longer correct to speak of the rules in question as moral rules, for to the extent that such rules are effectively enforced by physical sanctions they are laws.

This distinction points to a defining feature of any legal system: namely, that its existence depends upon and extends only so far as the system's success in establishing a monopoly over the physical sanctions available for enforcement purposes, i.e., a monopoly of the available means of violence. ${ }^{61}$ Since what is required here is a monopoly, as a matter of principle only one set of rules can possess it (within a delimited territory or sphere of conduct) at a time. Consequently, it is

60. Id. at 175-76.

61. This formulation is not Hart's own, although he does coquette with such expressions as "official monopoly of 'sanctions," " $i d$. at 91 , and "centralized official "sanctions," id. at 95. Rather, it is a variation of Weber's definition of the modern state as "a human community that (successfully) claims the monopoly of the legitimate use of physical force within a given territory." M. Weber, Politics as a Vocation, in From MAX WEBER 78 (H. Gerth \& C.W. Mills eds. 1958). See generally I M. WEBER, supra note 45, at 56. Weber's formulation has been borrowed because it captures, in an especially succinct fashion, the gist of Hart's distinction between legal and moral sanctions. 
this feature of law which uniquely distinguishes it from all other forms of social control.

This may be seen by considering the following example. Imagine a society based upon an organized system of rules which are enforced by physical sanctions. Now suppose that there exists within this society a religious sect with a distinct set of rules governing certain aspects of the conduct of its members. If this sect seeks to enforce its rules through the use of physical sanctions, several things may happen: (1) The larger society may authorize ${ }^{62}$ the sect to use such sanctions, in which case the sect becomes an organ of the legal system; (2) the sect may be prohibited from using physical sanctions and acquiesce, in which case it remains a moral order; or (3) it may be prohibited from using physical sanctions and resist, in which case its resistance will either be successful and the sect will establish itself as an independent legal system, or it will be unsuccessful and the sect will be painfully reminded of its merely moral status. In any case, the conduct in question can be regulated by only one legal system at a time. Where different systems of rules compete for legal status, the outcome will be decided in favor of that system which acquires an effective monopoly over the available physical sanctions. Hart's contention that the typical form of legal pressure consists in "threats of physical punishment" may be seen as a hesitant and disguised way of stating the same point.

If law differs from morality with respect to the type of sanctions which it employs, it also differs, according to Hart, with respect to the mode of their administration. Typically, moral sanctions take the "form of a general diffused hostile or critical reaction." ${ }^{63}$ By contrast, legal sanctions are typically administered by a centralized official organ $^{64}$ which possesses the exclusive authority to punish violations of the law.

Thus, when an individual breaches a moral duty any other member of the moral community to which he belongs may impose the appropriate sanction (by an appeal to the wrongdoer's conscience, by evoking feelings of guilt, and so on). The right, or in some cases obligation, to

62. Of course, the larger society may simply ignore the sect's use of physical sanctions. In this case, the sect's status will remain ambiguous. So long as the larger society is ablc to prevent the sect from using physical sanctions, it is proper to speak of the sect as being authorized (perhaps tacitly) to use such sanctions; when the larger society is no longer able to prevent the sect from using physical sanctions, even though it continues to claim that the sect is merely one of its organs, the sect will in reality have acquired the status of a legal system. So long as the larger society ignores the sect's use of sanctions, its ability to prevent the sect from using them must remain in doubt. This doubt is removed only when the two orders are brought into actual conflict.

63. HART 84.

64. Id. at 95 . 
impose such a sanction is not limited to a determinate segment of the moral community; if it exists at all, it may be exercised by any member of the community, acting as the community's representative. It is not the case, however, that when a rule of law is broken, every member of the legal community is equally qualified to inflict an appropriate punishment upon the wrongdoer. The right and ability to impose legal sanctions rests exclusively with a determinate class of officials, who are alone empowered to act in the name of the legal system. The reason for restricting the administration of legal sanctions in this way is obvious: Since legal sanctions always potentially ${ }^{65}$ involve physical violence, their free use must be curtailed if an organized and ongoing social life is to be possible at all. Thus, the mode of administration characteristic of legal sanctions is a consequence of the distinctive form that such sanctions typically assume. Legal sanctions must be officially administered because they are often actually and always potentially physical in nature.

\section{Summary}

Hart's definition of a legal system may be summarized in the following way: A legal system is a union of primary and secondary rules, embodying a "minimum content of Natural Law," and enforced by a determinate class of officials possessing an effective monopoly over the available physical sanctions within a delimited territory or sphere of conduct. Although Hart never states this definition in such an explicit and unequivocal fashion, it constitutes-to borrow Hart's own phrasethe "core of good sense" 66 in his analysis of the distinctive structure of municipal law. Since only one system of rules can successfully claim such a monopoly at any given time and with respect to any particular portion of human conduct, it follows that this definition uniquely distinguishes legal systems from all other forms of social control. Other definitions which may be extracted from The Concept of Law fail to do this, and must be rejected as inadequate. The pivotal center of Hart's concept of a legal system is to be found not in his analysis of rules, or in his discussion of the "minimum content of Natural Law," or even in the first three arguments which he gives for distinguishing law from morality, but in his discussion, limited as it may be, of the distinctiveness of legal sanctions.

65. It is important to keep in mind that on the view being urged here, it is not necessary that every legal infraction actually be punished by the application of a physical sanction; it is sufficient that those responsible for administering the law have monopolized the capacity for imposing such sanctions.

66. Id. at 194 . 


\section{Austin's Concept of a Legal System}

According to John Austin, it is the "principal purpose" of his main work in the philosophy of law "to describe the boundary which severs the province of jurisprudence from the regions lying on its confines," and to define "the appropriate matter" 68 with which the science of law is concerned. In the course of his six lectures on jurisprudence, Austin attempts to distinguish "laws which are simply and strictly so called and which form the appropriate matter of general and particular jurisprudence" from divine law, positive morality, and all laws "merely metaphorical or figurative." 69

"The matter of jurisprudence," on Austin's view, "is positive law: law, simply and strictly so called: or law set by political superiors to political inferiors."70 Law "strictly and simply so called" is, however, only one species of the wider and more inclusive category of law in general, which also includes positive morality and divine law. Austin defines the general concept of law in the following way: "a law, in the most general and comprehensive acceptation in which the term, in its literal meaning, is employed, may be said to be a rule laid down for the guidance of an intelligent being by an intelligent being having power over him."71

It is important to notice, first, that Austin's definition not only speaks of a "rule," but it includes, as part of the concept of law in general, an idea of "reason" or "intelligence" not unlike the notion of a "critical reflective attitude" which Hart employs to distinguish rulegoverned behavior from habit. ${ }^{72}$ When intelligence is missing, according to Austin, we can speak of law only in a "metaphorical or figurative" sense.

Such is the case when we talk of laws observed by the lower animals; of laws regulating the growth and decay of vegetables; of laws determining the movements of inanimate bodies or masses. For where intelligence is not, or where it is too bounded to take the name of reason and therefore is too bounded to conceive the purpose of a law, there is not the will which law can work on, or which duty can incite or restrain. ${ }^{73}$

An individual is not following a law (in the strict sense) when he merely acts in a regular and predictable manner; it is only when such

67. Ausrin, supra note 10 , at 2.

68. Id. at 3.

69. Id. at 1 .

70. Id. at 9 .

71. Id. at 10 .

72. HART 56.

73. Ausrin, supra note 10 , at 12-13. 
action is purposeful (i.e., is based upon the conception of a purpose) that it may be described as lawful "in the literal acceptation of the term." "74

In the second place, "laws or rules, properly so called, are a species of commands...."75 A command is an order laid down "for the guidance of an intelligent being" by another intelligent being superior to him, and "distinguished from other significations of desire, not by the style in which the desire is signified, but by the power and the purpose of the party commanding to inflict an evil or pain in the case the desire be disregarded."76 According to Austin, "the term superiority signifies might: the power of affecting others with evil or pain, and of forcing them, through fear of that evil, to fashion their conduct to one's wishes."77

"Laws properly so called" cannot be defined, however, simply as rules laid down by one intelligent being for the guidance of another intelligent being inferior to him, since this definition applies with equal validity to divine law and positive morality. Divine laws are laid down by an intelligent being who is "emphatically the superior of Man,"78 and whose power over man is "unbounded and resistless."70 Positive moral rules, as Austin views them, are "imperative laws or rules set by men to men,"s0 and backed by "moral sanctions." 81

In order to determine the "province of jurisprudence" it is therefore necessary to distinguish positive law both from divine law and positive morality. According to Austin, divine laws are "laws set by God to his human creatures." 82 The duties imposed by such laws "may be called religious duties" and their violations "are styled sins." 83 By contrast, the rules of positive law are "set by men to men," 84 that is, they are established and enforced by human beings.

Although this difference in authorship distinguishes divine from positive law, it does not distinguish positive law from positive morality, since the rules of positive morality are also, on Austin's view, "set by men to men." "Laws set by men to men are of two leading or principal classes" which "should be severed precisely, and opposed distinctly and conspicuously." 85 On the one hand,

\footnotetext{
74. Id. at 12 .

75. Id. at 13 .

76. Id. at 14 .

77. Id. at 24.

78. Id.

79. Id.

80. Id. at 135 .

81. Id. at 157 .

82. Id. at 34 .

83. Id.

84. Id.

85. Id. at $10-11$.
} 
of the laws set by men to men, some are established by political superiors, sovereign and subject: by persons exercising supreme and subordinate government, in independent nations, or independent political societies. The aggregate of the rules thus established, or some aggregate forming a portion of that aggregate, is the appropriate matter of jurisprudence general or particular. ${ }^{\text {s6 }}$

On the other hand,

though some of the laws or rules, which are set by men to men, are established by political superiors, others are not established by political superiors, or are not established by political superiors, in that capacity or character. ${ }^{87}$

Rules of the latter sort belong to positive morality. "Laws properly so called," in contradistinction to the rules of positive morality, are laid down for the guidance of men by their political superiors. From this it follows, according to Austin, that rules of positive law "are clothed with legal sanction,"ss whereas rules of positive morality are not.

\section{According to Austin,}

the superiority which is styled sovereignty, and the independent political society which sovereignty implies, is distinguished from other superiority and from other society, by the following marks or characters: 1 . The bulk of the given society are in a habit of obedience or submission to a determinate and common superior: let that common superior be a certain individual person, or a certain body or aggregate of individual persons. 2. That certain individual, or that certain body of individuals, is not in a habit of obedience to a determinate human superior. ${ }^{89}$

On its face this definition is a puzzling one since it does not distinguish political society in any special respect. We can easily imagine a moral institution-for example, a church-which exhibits both of the features that Austin treats as the distinguishing marks of an independent political society. In order to appreciate its full meaning, it is necessary to set Austin's definition of political sovereignty in its proper context, and explicate his notion of "a habit of obedience to a determinate and common superior."

Generally speaking, it is Austin's view that one individual is bound

86. Id. at 11 .

87. Id.

88. $7 d$. at 136 .

89. Id. at 193-94. 
or obliged to obey the command of another if the party commanding has the "power and the purpose" to "inflict an evil or a pain" his command is disobeyed. Consequently, one may be said to be in a "habit of obedience" to another when the power of that other to "inflict an evil or a pain" in case of disobedience is not merely occasional or temporary, but is "frequent or lasting." 91 Where only one determinate person or group of persons possesses such "frequent and lasting" power over others, the "mutual relation" which subsists between them "may be styled the relation of sovereign and subject, or the relation of sovereignty and subjection."

Unfortunately, Austin does not explicitly define the essential nature of sovereign power more specifically than this. As a result, the distinction which he wishes to draw between legal and moral power remains unclear. Austin's general definition of sovereignty fits both equally well. It is possible, however, to extract a more precise definition of legal power from an example which Austin employs to illustrate his conception of sovereignty, the example of "intestine war." 93

According to Austin, a society torn by civil strife may be "in one of ... two positions."94 "If the bulk of each of the [warring] parties be in a habit of obedience to its head, the given society is broken into two or more societies, which, perhaps, may be styled independent political societies.-If the bulk of each of the parties be not in that habit of obedience, the given society is simply or absolutely in a state of nature or anarchy." 95 This passage is most easily read as standing for the proposition that an independent political society exists only insofar as and to the extent that its head is able to impose physical sanctions upon those who disobey his commands, and that furthermore the power to impose such sanctions presupposes an effective monopoly of the means of violence within a particular jurisdiction (defined either with respect to persons or territory). ${ }^{90}$

90. Id, at 14 .

91. Id. at 206.

92. Id. at 194 .

93. Id. at 198 .

94. Id. at 198 .

95. Id.

96. This interpretation is supported by Austin's brief discussion of the Iegality of revolutionary governments. In considering the Mexican Revolution, Austin poses the following question: "When did the revolted colony, which is now the Mexican Nation, ascend from the condition of an insurgent province to that of an independent community? ... Or (adopting the current language about governments de jure and de facto) when did the body of colonists, who affected sovereignty in Mexico, become sovercign in fact?" AUsTIN, supra note 10, at 206. Austin's answer is that the sovereignty of the Mexican Nation was established precisely when the obedience of the inhabitants of Mexico to that body became so "frequent and lasting" that they were able to remain in a permanent "state of practical independence" from Spain. Id. But in what could such "practical 
If we put Austin's remarks about civil war together with what he has to say about the concepts of power, habit, sovereignty, and law in general, we arrive at the following definition of a legal system: A legal system is a set of rules laid down for the guidance of human beings, by a determinate person or group of persons having power over them by virtue of their effective monopolization of the physical sanctions within a particular jurisdiction (however defined).

\section{Conclusion}

Hart summarizes his long and detailed criticism of Austin's concept of a legal system in the following way:

The root cause of failure is that the elements out of which the theory was constructed, viz. the ideas of orders, obedience, habits, and threats, do not include, and cannot by their combination yield, the idea of a rule, without which we cannot hope to elucidate even the most elementary forms of law. ${ }^{97}$

A "fresh start" is needed, Hart tells us, if we are to have a "better account" of what a legal system is. 98 Hart's "better account" begins with the idea of a rule. More particularly, it begins with the idea of two distinct kinds of rules, which Hart terms primary and secondary. Hart flatly asserts that in "the combination of these two types of rule there lies what Austin wrongly claimed to have found in the notion of coercive orders, namely, 'the key to the science of jurisprudence.' "90

We have already seen that Hart's analysis of primary and secondary rules is not, by itself, sufficient to distinguish legal from other forms of social control.100 The most convincing basis which Hart offers for isolating the "distinctive structure of a municipal legal system" is to be found in his brief account of the nature of legal sanctions. This is the true center of Hart's concept of a legal system and far from representing an "advance" or "fresh start" in jurisprudence, it merely reproduces the analysis of legal sanctions offered by John Austin more than a century before. It may be that Hart was so preoccupied with

independence" consist, if not in the Mexican government's effective monopoly over the physical sanctions available for enforcing its laws within a specified territory? It may be difficult, of course, to determine precisely when such a monopoly was achieved. Nevertheless, Austin's argument points to the conclusion that in principle it was "at that juncture exactly", id., that the sovereign legal system of the Mexican Nation came into being.

97. HART 78.

98. Id.

99. Id. at 79 .

100. See p. 589 supra. 
freeing English jurisprudence from what he regarded as a mistaken conception of rules, that he simply failed to see how closely his overall account of what a legal system is resembles the account of the philosopher that Hart made his principal polemical adversary in formulating his own theory of rule-governed behavior. This failure dramatically demonstrates the influence which a particular picture of law, in which physical sanctions are given a preeminent place, continues to exercise over the imagination of even the best legal philosophers. ${ }^{101}$

101. As further confirmation of this influence, it is interesting to note that Hart's concept of a legal system turns upon a theory of sanctions remarkably similar to the one advanced by Hans Kelsen. See H. Kelsen, The Pure Theory of LAw 54 (M. Knight transl. 1967):

[A] definition of law, which does not determine law as a coercive order, must be rejected (I) because only by including the element of coercion into the definition of law is the law clearly distinguished from any other social order; (2) because coercion is a factor of great importance for the cognition of social relationships and highly characteristic of the social orders called 'law'; and, (3), particularly, because by defining law as a coercive order, a connection is accounted for that exists in the case most important for the cognition of the law, the law of the modern state: the connection between law and the state. The modern state is essentially a coercive ordera centralized coercive order, limited in its territorial validity.

Kelsen also claims:

$A$ difference between law and morals cannot be found in what the two social orders command or prohibit, but only in how they command or prohibit a certain behavior. The fundamental difference between law and morals is: law is a cocrcive order, that is, a normative order that attempts to bring about a certain behavior by attaching to the opposite behavior a socially organized coercive act; whereas morals is a social order without such sanctions. The sanctions of the moral order are merely the approval of the norm-conforming and the disapproval of the norm-opposing behavior, and no coercive acts are prescribed as sanctions.

Id. at 62. Kelsen defines "sanction" (much as John Austin did) as "the forcible infliction of an evil," or "the forcible deprivation of a value." Id. at 108 .

Hart recognizes Kelsen's similarity to Austin. HART 18. He fails, however, to see his own similarity to both. 